\title{
REPRESENTASI NILAI-NILAI PANDANGAN HIDUP ORANG SUNDA DALAM MOBILE APPS KISAH LUTUNG KASARUNG (ANALISIS SEMIOTIKA ROLAND BARTHES)
}

\author{
Dicky Hidayat ${ }^{1}$, Mohd. Asyiek Bin Mat Desa ${ }^{2}$ \\ 1 Program Studi Desain Komunikasi Visual, Univeristas Telkom Jl. Telekomunikasi No. 01, \\ Terusan Buah Batu, Bandung, Indonesia \\ 1,2Pusat Pengajian Seni, Universiti Sains Malaysia, 11800 Gelugor, \\ Penang, Malaysia \\ dickyhidayat@telkomuniversity.ac.id, Asyiekdesa@gmail.com
}

\begin{abstract}
Abstrak: Mobile apps merupakan salah satu bentuk multimedia yang dapat dimanfaatkan untuk tujuan pembelajaran. Mobile apps Kisah Lutung Kasarung merupakan bentuk adaptasi pantun Sunda ke dalam multimedia sebagai upaya mempertahankan nilai-nilai budaya lokal, sekaligus menangkal pengaruh-pengaruh negatif budaya asing yang saat ini kian merasuk ke dalam seluruh aspek kehidupan masyarakat. Penelitian ini bertujuan untuk mengidentifikasi representasi pandangan hidup Orang Sunda yang terkandung dalam mobile apps Kisah Lutung Kasarung. Penelitian yang dilakukan merupakan penelitian kualitatif deskriptif, dengan menggunakan analisis semiotika dari Roland Barthes, untuk menemukan representasi teks budaya berupa pandangan hidup Orang Sunda, yang mewujud dalam mobile apps tersebut. Hasil penelitian menunjukkan adanya nilai-nilai pandangan hidup Masyarakat Sunda yang disampaikan melalui mobile apps Kisah Lutung Kasarung. Dengan demikian dapat disimpulkan bahwa mobile apps dalam bentuk cerita anak interaktif merupakan media yang dapat dimanfaatkan sebagai media pembelajaran tentang nilai-nilai pandangan hidup orang Sunda untuk anak-anak.
\end{abstract}

Kata kunci: mobile apps, pandangan hidup, Sunda, Lutung Kasarung

\begin{abstract}
Mobile apps is one form of multimedia that can be used for learning. Mobile apps The story of Lutung Kasarung is a Sundanese pantun that was adapted into multimedia in an effort to maintain local cultural values, while counteracting the negative influences of foreign cultures which are now increasingly pervading all aspects of people's lives. This study aims to identify the representation of the Sundanese people's worldviews contained in the mobile apps The Story of Lutung Kasarung. The research conducted is descriptive qualitative research, using semiotic analysis from Roland Barthes to find a representation of cultural texts that manifest in Multimedia Elements and Story Elements contained in these mobile apps. The results of the study indicate the existence of the values of the life views of the Sundanese people which are conveyed through the mobile apps The Story of Lutung Kasarung. Thus the mobile apps in the form of interactive children's stories are media that can be used as a medium of learning about the values of the Sundanese worldviews.
\end{abstract}

\footnotetext{
${ }^{1}$ Dosen pada prodi S1 Desain Komunikasi Visual, Fakultas Industri Kreatif, Telkom University. Fokus penelitian pada revitalisasi nilai-nilai tradisional melalui multimedia.

${ }^{2}$ Senior Lecture pada Pusat Pengkajian Seni, Universiti Sains Malaysia. Dept. New Media, Design \& Technology.
} 
Keywords: mobile apps, worldview, Sunda, Lutung Kasarung

\section{PENDAHULUAN}

Pandangan hidup merupakan salah satu unsur kebudayaan yang berperan penting dalam membentuk karakter suatu masyarakat. Menurut Siswanto (2010: 203) pandangan hidup adalah abstraksi dari pengalaman hidup yang dibentuk oleh suatu cara berpikir dan cara merasakan tentang nilai-nilai, organisasi sosial, kelakuan, peristiwa-peristiwa dan segi-segi lain dari pengalaman. Dengan demikian pandangan hidup merupakan pengaturan mental dari pengalaman untuk mengembangkan suatu sikap hidup. Selanjutnya Siswanto (2010: 204) menjelaskan bahwa pandangan hidup adalah wawasan secara menyeluruh mengenai kehidupan yang terdiri dari kesatuan nilai-nilai luhur, yaitu tolak ukur kebaikan yang berkaitan dengan berbagai hal mendasar dan abadi dalam kehidupan manusia. Pandangan hidup berfungsi sebagai kerangka acuan dalam menata kehidupan diri pribadi, hubungan antara manusia dengan masyarakat, dan hubungan antara manusia dengan alam sekitar.

Orang Sunda memiliki nilai-nilai pandangan hidup yang diwariskan dari generasi ke generasi. Pandangan hidup tersebut membentuk karakter Orang Sunda yang dikenal secara umum memiliki sifat yang lemah lembut, gemulai, sopan santun, dan didasari oleh nilai-nilai silih asih, silih asah, dan silih asuh. Ajip Rosidi (2010 : 58-61) menyatakan bahwa pandangan hidup Masyarakat Sunda dapat dibagi dalam lima kategori yaitu pandangan hidup tentang : 1) manusia sebagai pribadi (MP), yaitu Orang Sunda harus memiliki tujuan yang baik, mengganggap dirinya sebagai bagian dari alam semesta, sopan, sederhana, jujur, teguh pendirian dalam kebenaran dan keadilan, baik hati, dapat dipercaya, menghormati dan menghargai orang lain, dapat mengendalikan diri, serta cinta tanah air dan bangsa; 2) manusia dengan lingkungan masyarakatnya (MM), yaitu Orang Sunda harus memiliki semangat bekerjasama, saling hormat dan 
bertatakrama, saling sayang, sopan dalam berkata, bersikap, dan berperilaku; 3) manusia dengan alam (MA), yaitu bahwa alam akan memberikan manfaat untuk manusia apabila manusia dapat melestarikan, memelihara, dan merawatnya dengan baik, dan memanfaatkan secukupnya saja; 4) manusia dengan Tuhan (MT), bagi Orang Sunda Tuhan Yang Maha Esa yang memberikan kesehatan dan rizki, serta mematikannya pada waktunya, oleh karena itu sebagai manusia Sunda, individu wajib berbakti dan mengabdi kepada Tuhan; 5) manusia dalam mengejar kepuasan lahiriah dan batiniah (MK), Orang Sunda kurang menyukai persaingan, lebih suka kerjasama, kerja keras, pantang menyerah, lebih mengutamakan kualitas daripada kecepatan dalam bekerja.

Seiring dengan perkembangan jaman, dan akibat masuknya nilai-nilai budaya dari luar lingkungan sosialnya, pemahaman terhadap nilai-nilai pandangan hidup orang Sunda saat ini sudah semakin memudar. Hal tersebut dapat dilihat dalam kehidupan sehari-hari seperti berkurangnya nilai-nilai sopan santun di kalangan anak-anak dan remaja, maraknya perilaku-perilaku kenakalan dan kejahatan, berkurangnya rasa hormat pada orang tua dan guru, dan kurangnya kepedulian terhadap lingkungan. Banyak upaya telah dilakukan oleh berbagai pihak untuk mempertahankan dan melestarikan nilai-nilai karakter dan pandangan hidup Orang Sunda tersebut, baik melalui pendidikan karakter secara formal di sekolah, maupun nonformal dan informal di dalam keluarga dan masyarakat. Pada dasarnya pendidikan karakter yang bertujuan untuk mendidik watak, akal, budi, dan aspek-aspek kejiwaan lainnya ini, sebaiknya dilakukan pada usia dini, dan dengan penggunaan media dan teknologi yang tepat dapat mengoptimalkan hasil pendidikan agar sesuai dengan yang diharapkan.

Pemanfaatan teknologi multimedia sebagai media pembelajaran dapat mengoptimalkan hasil dari suatu proses pendidikan. Multimedia merupakan konsep dan teknologi dari elemen-elemen gambar, suara, animasi, serta video 
yang digabungkan, disimpan, diproses, dan disajikan dalam komputer untuk membentuk interaktif yang sangat inovatif antara komputer dengan pengguna (Munir, 2012: 138). Perkembangan teknologi dibidang multimedia berpotensi besar dalam mengubah cara belajar, memperoleh informasi, menyesuaikan informasi dan sebagainya (Kusmayadi, Suyitno dan Maryaeni, 2017: 902). Potensi ini memberi kesempatan bagi penggiat pelestarian budaya tradisi untuk memanfaatkan multimedia sebagai sarana pembelajaran nilai-nilai tradisi kepada anak-anak dan remaja.

Salah satu bentuk multimedia yang dapat dipergunakan adalah dalam bentuk mobile apps, yaitu salah satu bentuk multimedia yang dapat dioperasikan melalui perangkat smartphone atau tablet. Untuk dapat mengoperasikan mobile apps pengguna terlebih dahulu harus mengunduh dan menginstal aplikasinya melalui toko aplikasi secara daring seperti Play Store, Apple App Store, atau Blackberry App. Mobile apps saat ini tersedia untuk digunakan di berbagai platform seperti Android, iOS, Blackberry, dan Windows Phone.

Pengguna smartphone saat ini sudah semakin luas dan masif. Penggunanya tidak hanya terbatas pada orang dewasa tapi juga anak-anak. Kondisi ini memberi peluang bagi pengembang digital content untuk membuat berbagai mobile apps yang ditujukan untuk pangsa pasar anak-anak. Daya tarik mobile apps bagi anakanak, terutama dalam menyajikan berbagai permainan digital yang menarik, dapat dimanfaatkan sebagai media pendidikan.

Penggunaan mobile apps untuk tujuan pendidikan sangat dimungkinkan, karena multimedia memiliki potensi yang baik dalam menyampaikan dan merepresentasikan materi pembelajaran yang dikandung di dalamnya. Menurut teori semiotika representasi dipahami sebagai proses pemaknaan gagasan, pengetahuan, atau pesan secara fisik yang menunjuk baik pada proses maupun peristiwa dari pemaknaan tanda (Aldira, 2018: 48). Representasi merupakan 
tindakan atau upaya untuk menghadirkan ataupun mempresentasikan sesuatu baik orang, peristiwa, maupun obyek lewat sesuatu di luar dirinya, biasanya berupa tanda atau simbol (Hall, 2011: 24-25). Untuk mengidentifikasi bagaimana nilai-nilai pandangan hidup Orang Sunda direpresentasikan dalam mobile apps, dibutuhkan suatu model penelitian dengan menggunakan pendekatan yang berfokus pada makna tanda dan simbol.

Berdasarkan pemaparan tersebut, dapat dirumuskan bahwa masalah dalam penelitian ini adalah bagaimana makna denotatif, konotatif dan mitos dalam mobile apps KLK dapat merepresentasikan nilai-nilai pandangan hidup Orang Sunda dalam. Berdasarkan rumusan masalah tersebut maka tujuan dari penelitian ini adalah mengidentifikasi makna denotatif, konotatif dan mitos serta mengidentifikasi representasi nilai-nilai pandangan hidup Orang Sunda dalam mobile apps KLK.

Penelitian ini diharapkan dapat bermanfaat sebagai masukan dan pertimbangan bagi para pengembang mobile apps, khususnya pengembang mobile apps lokal dan umumnya bagi pengembang content digital di dalam mengadaptasi nilai-nilai budaya tradisi. Manfaat teoritis dari penelitian ini diharapkan dapat memberi sumbangan bagi pengembangan ilmu pengetahuan di bidang desain, multimedia, kajian budaya, serta dapat dijadikan pijakan bagi penelitian selanjutnya.

\section{METODE PENELITIAN}

Penelitian yang dilakukan merupakan penelitian kualitatif desktriptif dengan menggunakan pendekatan semiotika Roland Barthes, untuk menganalisis berbagai teks yang terdapat pada obyek penelitian. Teks dalam pengertian yang lebih luas adalah pesan-pesan berupa tanda verbal maupun visual (visual signs), yang menghasilkan teks verbal dan teks visual (visual text), seperti gambar iklan, 
televisi, komik, film, fashion, seni tari, teater, patung, arsitek, tatakota (Piliang, $2004: 190)$.

Semiotika visual (visual semiotics) merupakan salah satu bidang studi semiotika yang secara khusus menaruh minat pada penyelidikan terhadap segala jenis makna yang disampaikan melalui sarana indra penglihatan (Budiman, 2011: 9). Roland Barthes merupakan salah satu tokoh penting dalam semiotika. Barthes memfokuskan penelitiannya pada tanda-tanda non-verbal. Pada bukunya yang berjudul Mythologies Barthes menerapkan semiologi terhadap obyek-obyek kultural. Barthes menyatakan bahwa ada dua tingkat dalam pertandaan yaitu denotasi (denotation) dan konotasi (konotation). Denotasi adalah makna paling nyata dari tanda (sign), merujuk pada realitas yang menghasilkan makna yang eksplisit, langsung dan pasti. Sedangkan pada konotasi terdapat makna yang tidak sebenarnya, tidak eksplisit, tidak langsung, tersembunyi dan tidak pasti (terbuka bagi berbagai kemungkinan).

Barthes berpendapat bahwa konotasi merupakan operasi ideologi atau mitos, yaitu cara berpikir kebudayaan untuk menjelaskan dan memahami berbagai realitas dan gejala alam serta pengkodean makna dan nilai-nilai sosial (Aldira, 2018: 5). Menurut Barthes bahasa (language) membutuhkan kondisi tertentu untuk dapat menjadi mitos, yaitu secara semiotis dicirikan oleh hadirnya sebuah tatanan signifikasi yang disebut dengan semiologis tingkat kedua (the second order semiological system). Penanda-penanda pada semiotika tingkat kedua ini merupakan retorik atau konotator-konotator yang tersusun dari tandatanda sistem pertama. Roland Barthes menyatakan bahwa sesuatu yang tertulis atau sekedar representasi, verbal maupun visual, secara potensial dapat menjadi mitos (Budiman, 2011: 41) 


\begin{tabular}{|c|c|c|c|}
\hline \multirow[b]{2}{*}{ language } & $\begin{array}{l}\text { 1. Signifier } \\
\text { (penanda) }\end{array}$ & $\begin{array}{l}\text { 2. Signified } \\
\text { (petanda) }\end{array}$ & \multirow[b]{2}{*}{ II. Signified (petanda konotatif) } \\
\hline & \multicolumn{2}{|c|}{$\begin{array}{l}\text { 3. Sign (tanda denotatif) } \\
\text { I.Signifier (penanda konotatif) }\end{array}$} & \\
\hline myth & \multicolumn{3}{|c|}{$\begin{array}{c}\text { III. Sign } \\
\text { (tanda konotatif) }\end{array}$} \\
\hline
\end{tabular}

Gambar 1 Semiotika Roland Barthes

Sumber: Budiman, 2011

Penelitian diawali dengan cara pengamatan terhadap berbagai mobile apps yang mengandung konten atau bertema budaya Sunda. Tahap berikutnya adalah menetapkan mobile apps apa yang akan dijadikan obyek penelitian, indikator yang dipergunakan adalah tingkat popularitas berdasarkan jumlah pengunduh mobile apps tersebut pada Play Store. Pengumpulan data-data dilakukan dengan cara observasi, dokumentasi dan studi pustaka. Analisis data dilakukan dengan teknis analisis data dari Milles dan Huberman, yaitu pengumpulan data, reduksi data, penyajian data dan penarikan kesimpulan.

Model analisis visual (visual analysis) dengan pendekatan semiotika Roland Barthes digunakan untuk mengidentifikasi representasi nilai-nilai karakter dan pandangan hidup Orang Sunda yang terdapat pada obyek penelitian. Analisis visual ini dilakukan melalui tahap deskripsi, analisis, interpretasi dan penilaian (Soewardikoen, 2013: 11).

\section{HASIL DAN DISKUSI}

Berdasarkan pengamatan terhadap berbagai mobile apps yang terdapat di Play Store, yaitu portal untuk mengunduh mobile apps bagi pengguna smartphone berbasis android, ditemukan bahwa mobile apps yang ditawarkan terbagi dalam kategori game, aplikasi, film, dan buku. Pada kategori aplikasi terdapat sub kategori aplikasi keluarga yang merupakan salah satu aplikasi paling populer di Play Store. Pada kategori aplikasi keluarga tersebut terdapat berbagai mobile apps bertema 
pendidikan dalam bentuk aplikasi cerita anak interaktif yang bersumber pada cerita rakyat Nusantara, termasuk diantaranya cerita rakyat yang berasal dari tanah Sunda atau Jawa Barat.

Educa Studio merupakan perusahaan pengembang konten digital lokal yang produktif mengembangkan mobile apps. Salah satu produknya adalah serial cerita anak-anak RIRI. Serial cerita anak interaktif ini mengangkat tema ceritacerita rakyat asli dari Indonesia serta dongeng dari seluruh dunia. Dari sekian banyak cerita anak interaktif yang dibuat oleh perusahaan pengembang konten digital dari Kota Salatiga ini terdapat beberapa cerita anak interaktif yang mengadaptasi cerita rakyat dari tanah Sunda seperti Kisah Lutung Kasarung, AsalUsul Tangkuban Perahu, Monyet dan Kura-kura, dan lain-lain. Mobile apps cerita anak interaktif Kisah Lutung Kasarung (KLK) merupakan salah satu mobile apps yang paling populer. Mobile apps ini merupakan adaptasi dari cerita Lutung Kasarung, cerita rakyat Jawa barat yang bersumber dari cerita pantun Sunda.

Cerita rakyat KLK menceritakan kisah Purbasari yang direbut tahtanya dan diusir dari istana oleh Purbararang, saudara perempuannya yang pendengki. Dengan tubuh berbau dan penuh bentol akibat ramuan sihir, Purbasari dibuang ke dalam hutan. Selama di hutan Purbasari berteman dengan seekor kera berbulu hitam yang diberi nama Lutung Kasarung. Berkat bantuan Lutung Kasarung, Purbasari sembuh dari penyakitnya. Purbararang kemudian menantang adu panjang rambut, dan adu ketampanan tunangannya masing-masing. Lutung Kasarung kemudian berubah menjadi pangeran yang tampan dan Purbasari memenangkan segala tantangan yang diberikan Purbarang. Akhirnya Purbasari menikah dengan pemuda gagah dan tampan jelmaan Lutung Kasarung. Purbasari memaafkan kakaknya dan menjadi ratu yang adil dan bijaksana. Pada halaman akhir dari cerita interaktif tertulis pesan moral: "Segala niat dan perbuatan jahat 
pasti akan mendapat balasannya. Mau memaafkan orang lain adalah sifat yang terpuji. Nah, ayo kita saling memaafkan".

Mobile apps KLK merupakan aplikasi multimedia yang memadukan cerita interaktif dan edukasi interaktif dalam satu aplikasi. Dalam mode cerita interaktif pengguna memiliki dua pilihan menu, yaitu otomatis dan baca sendiri. Mode otomatis akan menjalankan cerita secara otomatis dari halaman awal sampai akhir. Sementara dengan mode baca sendiri pengguna dapat secara bebas memilih halaman yang dikehendaki dengan menekan tombol yang telah disediakan.
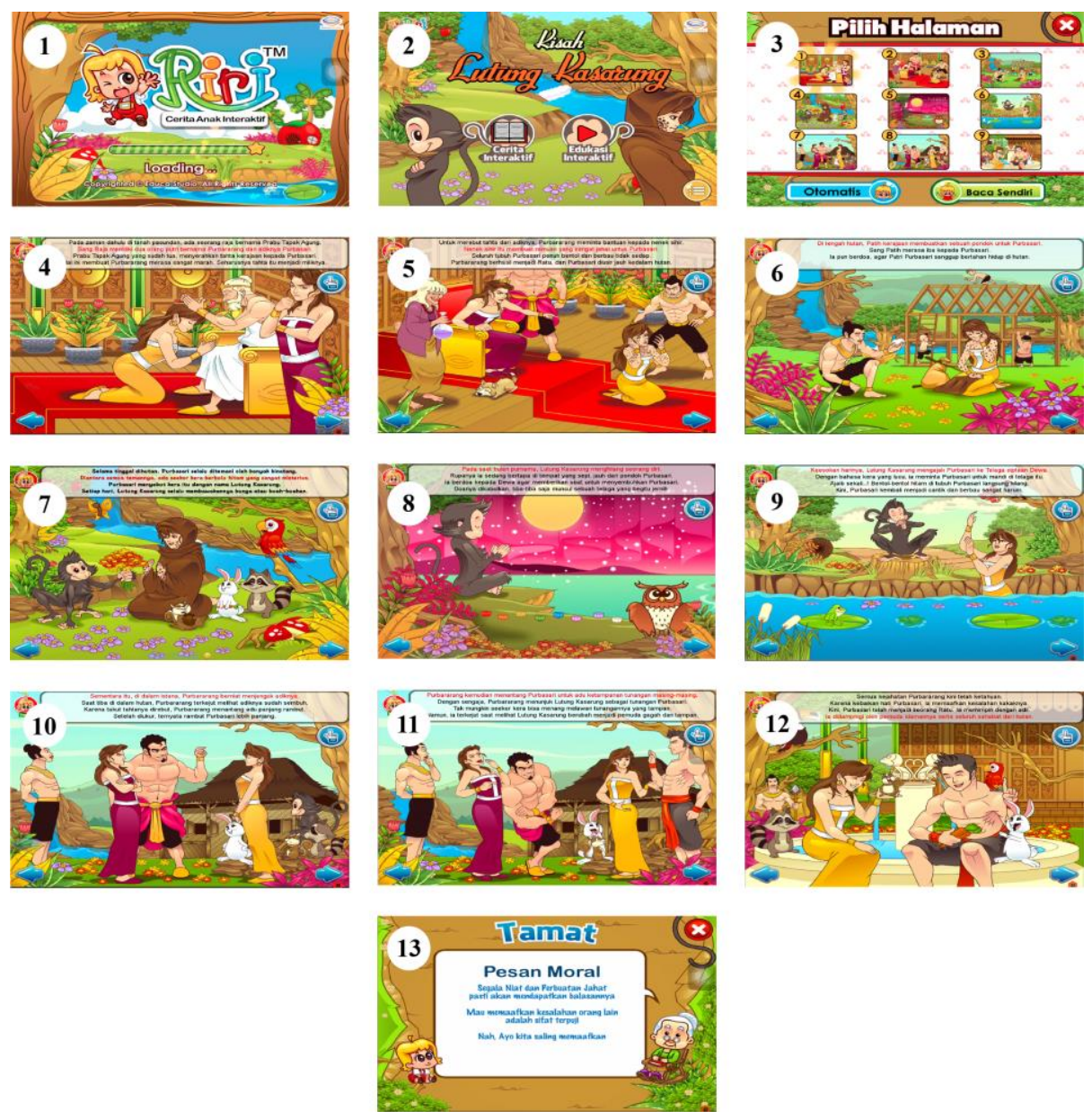

Gambar 2 Scene pada mobile apps KLK

Sumber: Educa studio, 2019 
Dalam model Edukasi Interaktif terdapat empat buah game yang dapat dimainkan yaitu puzzle bentuk, dress up, basuh tubuh dan ulat buah. Keempat games kombinasi antara genre Arcade dan Puzzle, yaitu genre games yang berintikan pemecahan teka-teki dan fokus dalam mengejar skor. Ke empat games ini cukup menarik, dapat dengan mudah dimainkan oleh anak-anak, serta memiliki keterkaitan dengan jalan cerita interaktif Lutung Kasarung.

Untuk memudahkan proses penguraian makna denotatif, konotatif dan mitos, maka dilakukan pembagian berdasarkan scene-scene yang terdapat pada mobile apps KLK. Berdasarkan pembagian tersebut dihasilkan sejumlah 13 scene yang selanjutnya diberi nomor dari 01 sampai dengan 13 . Scene-scene tersebut menjadi unit analisis data yang akan teliti melalui tahap deskripsi, analisis, interpretasi dan penilaian untuk mengidentifikasi makna denotasi, konotasi dan mitos yang merepresentasikan nilai-nilai pandangan hidup Orang Sunda pada mobile apps tersebut.

\begin{tabular}{|l|l|}
\hline $\mid$ & $\begin{array}{l}\text { Scene di samping mengambarkan } \\
\text { suasana dalam sebuah ruangan istana. } \\
\text { Terdapat tiga orang dalam ruangan } \\
\text { tersebut, seorang laki-laki tua } \\
\text { memakai mahkota, dan dua orang } \\
\text { wanita. Wanita berbusana warna } \\
\text { kuning sedang menyembah kepada } \\
\text { laki-laki tua tersebut, sementara } \\
\text { wanita berbusana warna merah berdiri } \\
\text { dengan sikap sinis. }\end{array}$ \\
\hline (1. Signifier) & $\begin{array}{c}\text { Tiga orang dalam } \\
\text { sebuah ruangan } \\
\text { Istana dengan } \\
\text { sikap dan gestur } \\
\text { tubuh yang } \\
\text { berbeda } \\
\text { Signified) }\end{array}$ \\
\hline
\end{tabular}


Wanita berbusana warna kuning sedang menyembah kepada laki-laki tua tersebut, sementara wanita berbusana warna merah berdiri dengan sikap sinis.

(3. Sign denotatif/ I. Signifier konotatif)
Perbedaan sifat yang bertolak belakang antara wanita berbusana warna kuning dengan wanita berbusana warna merah

Menyembah kepada orang tua merepresentasikan sikap hormat dan tatakrama yang baik (III. Sign Konotasi) $\rightarrow$ Mitos

Gambar 3 Analisis semiotika Roland Barthes pada scene mobile apps KLK Sumber: Hidayat, 2019

Gambar 3 menunjukkan proses analisis visual melalui tahap deskripsi, analisis, interpretasi dan penilaian dengan menggunakan teori semiotika Roland Barthes. Untuk mengidentifikasi makna denotasi, konotasi dan mitos pada salah satu scene pada mobile apps KLK. Selengkapnya akan dipaparkan analisis visual yang dilakukan pada seluruh scene dari mobile apps KLK.

\section{Representasi Pandangan Hidup tentang Manusia sebagai Pribadi (MP)}

Dengan menggunakan analisis semiotika Roland Barthes terungkap bahwa representasi pandangan hidup Orang Sunda tentang manusia sebagai pribadi (MP) pada mobile apps KLK terdapat scene 01, 02, 04, 05, 06, 07, 08, 09, 10, 11, 12 dan 13. Kategori pandangan hidup yang ditemukan adalah memiliki tujuan yang baik (scene 06 dan 09), mengganggap dirinya sebagai bagian dari alam semesta (scene 07 dan 08), sopan (scene 01, 02, 04, 10, 11, dan 13), sederhana (scene 01, 02, 07, 10 dan 11), teguh pendirian dalam kebenaran dan keadilan (scene 05 dan 10), baik hati (scene 01, 02, 06, 07, 08, 09, 10, 12 dan 13), dapat dipercaya (scene 12), menghormati dan menghargai orang lain (scene 04 dan 06), dapat mengendalikan diri (scene 10 dan 11), dan cinta tanah air dan bangsa (scene 12).

Dari analisis yang telah dilakukan terungkap bahwa representasi pandangan hidup Orang Sunda tentang manusia sebagai pribadi (MP) yang paling banyak ditemukan pada mobile apps KLK adalah kategori pandangan hidup 
tentang sifat baik hati. Sementara yang paling sedikit ditemukan adalah pandangan hidup tentang sifat jujur dan dapat dipercaya.

\section{Representasi Pandangan Hidup tentang Manusia dengan Masyarakat (MM)}

Representasi pandangan hidup Orang Sunda tentang manusia dengan lingkungan masyarakatnya (MM) pada mobile apps KLK terdapat scene 01, 02, 04, $06,07,08,09,10,11,12$ dan 13 . Kategori pandangan hidup yang ditemukan adalah semangat bekerjasama/tolong menolong (scene 06, 08, 09), saling hormat dan bertatakrama (scene 04), saling sayang/memaafkan (scene 12,13), dan sopan dalam berkata, bersikap, dan berperilaku (scene $01,02,04,07,10,11,13$ ).

Dengan menggunakan analisis semiotika Roland Barthes terhadap mobile apps KLK, terungkap bahwa representasi pandangan hidup Orang Sunda tentang manusia dengan lingkungan masyarakatnya ( $\mathrm{MM})$, paling banyak ditemukan kategori pandangan hidup tentang manusia Sunda memiliki sifat sopan dalam berkata, bersikap, dan berperilaku. Sementara yang paling sedikit ditemukan adalah pandangan hidup bahwa Orang Sunda memiliki sifat saling hormat dan bertatakrama.

\section{Representasi Pandangan Hidup tentang Manusia dengan Alam (MA)}

Representasi pandangan hidup manusia tentang alam (MA) pada mobile apps KLK dapat ditemukan pada scene 01, 02, 03, 06 dan 07. Kategori pandangan hidup yang ditemukan adalah melestarikan, memelihara, dan merawat alam dengan baik (scene 01, 02, 03, dan 07), dan memanfaatkan alam secukupnya saja (scene 06).

Dari analisis yang telah dilakukan terungkap bahwa representasi pandangan hidup manusia tentang alam (MA) yang paling banyak ditemukan pada mobile apps KLK adalah pandangan hidup bahwa manusia harus melestarikan, memelihara, dan merawat alam dengan baik. Sementara yang paling sedikit 
ditemukan adalah pandangan hidup bahwa manusia harus memanfaatkan alam secukupnya saja.

\section{Representasi Pandangan Hidup tentang Manusia dengan Tuhan (MT)}

Representasi pandangan hidup tentang manusia dengan Tuhan (MT) pada mobile apps KLK ditemukan pada scene 08. Pandangan hidup ini menyatakan bahwa bagi Orang Sunda Tuhan Yang Maha Esa yang memberikan kesehatan dan rizki, serta mematikannya pada waktunya, oleh karenanya, sebagai manusia Sunda, individu wajib berbakti dan mengabdi kepada Tuhan Yang Maha Esa.

\section{Representasi Pandangan Hidup tentang Manusia dalam Mengejar Kepuasan} Lahiriah dan Batiniah (MK)

Representasi pandangan hidup tentang manusia dalam mengejar kepuasan lahiriah dan batiniah (MK) pada mobile apps KLK terdapat pada scene 05, 06, 07, 08, 10 dan 11. Kategori pandangan hidup yang ditemukan adalah kurang menyukai persaingan (scene 05, 10 dan 11), suka kerjasama (scene 06), kerja keras (scene 06) dan pantang menyerah (scene 07 dan 08).

Dari analisis yang telah dilakukan terungkap bahwa representasi pandangan hidup tentang manusia dalam mengejar kepuasan lahiriah dan batiniah (MK), yang paling banyak ditemukan adalah pandangan hidup bahwa manusia Sunda kurang menyukai persaingan. Sementara yang tidak ditemukan adalah pandangan hidup bahwa manusia Sunda lebih mengutamakan kualitas daripada kecepatan dalam bekerja.

\section{KESIMPULAN}

Bedasarkan hasil analisis dengan menggunakan teori semiotika Roland Barthes, ditemukan bahwa nilai-nilai pandangan hidup Orang Sunda dalam mobille apps KLK dapat ditemukan pada tanda-tanda yang muncul pada scene. Nilai-nilai pandangan hidup Orang Sunda tersebut merupakan mitos yaitu secara semiotis 
hadir pada tatanan signifikasi semiologis tingkat kedua (the second order semiological system). Penanda-penanda pada semiologis tingkat kedua ini merupakan retorik atau konotator-konotator yang tersusun dari tanda-tanda sistem pertama yang terdapat pada scene-scene mobile apps KLK. Hal ini sejalan dengan pendapat Roland Barthes yang menyatakan bahwa konotasi identik dengan operasi ideologi yang disebut dengan mitos, yaitu cara berpikir kebudayaan untuk menjelaskan dan memahami berbagai realitas dan gejala alam serta pengkodean makna dan nilai-nilai sosial.

Representasi pandangan hidup Orang Sunda yang paling banyak mewujud pada mobile apps KLK adalah kategori pandangan hidup tentang manusia sebagai pribadi (MP), khususnya pada pandangan hidup bahwa Orang Sunda harus memiliki sifat baik hati. Sementara representasi pandangan hidup yang sama sekali tidak tampil pada mobile apps KLK adalah kategori pandangan hidup tentang manusia dalam mengejar kebutuhan lahiriah dan kepuasan batiniah (MK), khususnya pada pandangan hidup bahwa Orang Sunda lebih mementingkan kualitas dari pada kuantitas dalam bekerja.

Tabel 1 Representasi pandangan hidup Orang Sunda pada mobile apps

kisah lutung kasarung

\begin{tabular}{|c|c|c|c|c|c|c|c|c|c|c|c|c|c|c|}
\hline \multirow{2}{*}{$\begin{array}{l}\text { Kate } \\
\text { gori }\end{array}$} & \multirow{2}{*}{ Pandangan Hidup } & \multicolumn{13}{|c|}{ Scene } \\
\hline & & 01 & 02 & 03 & 04 & 05 & 06 & 07 & 08 & 09 & 10 & 11 & 12 & 13 \\
\hline \multirow{11}{*}{ MP } & Memiliki tujuan yang baik & & & & & & V & & & V & & & V & \\
\hline & $\begin{array}{l}\text { Mengganggap dirinya } \\
\text { bagian dari alam semesta }\end{array}$ & & & & & & & V & V & & & & & \\
\hline & Sopan & V & V & & V & & & & & & V & V & & V \\
\hline & Sederhana & V & V & & & & & V & & & V & V & & \\
\hline & Jujur & & & & & & & & & & & & & \\
\hline & $\begin{array}{l}\text { Teguh Pendirian dalam } \\
\text { kebenaran dan keadilan }\end{array}$ & & & & & V & & & & & V & & & \\
\hline & Baik hati & V & V & & & & V & V & V & V & V & & V & V \\
\hline & Dapat dipercaya & & & & & & & & & & & V & & \\
\hline & $\begin{array}{l}\text { Menghormati dan } \\
\text { menghargai org lain }\end{array}$ & & & & V & & V & & & & & & & \\
\hline & Dapat mengendalikan diri & & & & & & & & & & V & V & & \\
\hline & Cinta tanah air dan bangsa & & & & & & & & & & & & $\mathrm{V}$ & \\
\hline
\end{tabular}




\begin{tabular}{|c|c|c|c|c|c|c|c|c|c|c|c|c|c|}
\hline \multirow{4}{*}{ MM } & $\begin{array}{l}\text { Semangat kerjasama/ } \\
\text { tolong menolong }\end{array}$ & & & & & & V & & V & $\mathrm{V}$ & & & \\
\hline & $\begin{array}{l}\text { Saling hormat dan bertata } \\
\text { krama }\end{array}$ & & & & V & & V & & & & & & \\
\hline & Saling sayang/memaafkan & & & & & & & & & & & V & $\mathrm{V}$ \\
\hline & $\begin{array}{l}\text { Sopan dalam berkata, } \\
\text { bersikap dan berperilaku }\end{array}$ & V & V & & V & & & V & & V & V & & V \\
\hline & $\begin{array}{l}\text { Melestarikan, memelihara } \\
\text { dan merawat alam }\end{array}$ & V & V & V & & & & V & & & & & \\
\hline MA & $\begin{array}{l}\text { Memanfaatkan alam } \\
\text { secukupnya }\end{array}$ & & & & & & V & & & & & & \\
\hline MT & $\begin{array}{l}\text { Percaya, berbakti dan } \\
\text { mengabdi kepada Tuhan }\end{array}$ & & & & & & & & V & & & & \\
\hline \multirow{5}{*}{ MK } & Kurang suka persaingan & & & & & V & & & & V & $\mathrm{V}$ & & \\
\hline & Suka kerjasama & & & & & & V & & & & & & \\
\hline & Kerja keras & & & & & & $\mathrm{V}$ & & & & & & \\
\hline & Pantang menyerah & & & & & & & V & V & & & & \\
\hline & $\begin{array}{l}\text { Lebih mengutamakan } \\
\text { kualitas dari pd kecepatan } \\
\text { dalam bekerja }\end{array}$ & & & & & & & & & & & & \\
\hline
\end{tabular}

Sumber : Hidayat, 2019

Berdasarkan temuan ini dapat disimpulkan bahwa mobile apps KLK sudah sesuai untuk dipergunakan sebagai media pembelajaran tentang karakter dan membentuk kepribadian anak, yaitu pandangan hidup bahwa orang Sunda harus memiliki sifat baik hati, sebagaimana dicontohkan oleh tokoh-tokoh yang terdapat pada mobile apps KLK tersebut. Hal ini juga menunjukkan bahwa pemanfaatan mobile apps sebagai media pendidikan tentang karakter kepada anak-anak sudah tepat, karena pendidikan karakter yang pada dasarnya bertujuan untuk mendidik watak, akal, budi, dan aspek-aspek kejiwaan lainnya sebaiknya dilakukan pada usia dini.

Selain menganalisis mitos berupa pandangan hidup Orang Sunda pada mobile apps KLK, penelitian juga menemukan berbagai satuan pembacaan berupa obyek visual yang oleh Roland Barthes disebut dengan leksia (lexias), dimana leksia-leksia tersebut memiliki beberapa kemungkinan makna. Leksia menurut Barthes dapat dikelompokkan dalam lima kode pokok yaitu kode hermeneutik, kode semik, kode simbolik, kode proairetik, dan kode kultural (Budiman, 2011: 34). Berdasarkan leksia-leksia tersebut dapat diamati bahwa secara keseluruhan 
mobille apps KLK belum sepenuhnya merepresentasikan nilai-nilai budaya Sunda secara lengkap, seperti sosok manusia, model busana, ornamen dan bentuk bangunan, senjata, musik latar, dan bahasa yang dipergunakan. Diperlukan penelitian lebih lanjut mengenai merepresentasi budaya Sunda pada mobile apps ini, untuk mendapatkan hasil penelitian yang lebih lengkap dan menyeluruh.

\section{DAFTAR PUSTAKA}

Aldira, Nabila Putri. 2018. Representasi Nilai-Nilai Bhinneka Tunggal Ika dalam Film Tabula Rasa (Analisis Semiotika Roland Barthes). JOM FISIP, 5 (1). 1-10.

Astleitner, Hermann. 2004. Multimedia Element and Emotional Processes. EJournal of Instructional Science and Technology, 7(2).

Budiman, Kris. 2011. Semiotika Visual, Konsep, Isu, dan Problem Ikonitas. Yogyakarta : Jalasutra.

Ekadjati, Edi S. 1995. Kebudayaan Sunda (Suatu Pendekatan Sejarah). Jakarta : Pustaka Jaya.

Fiske, John. 2007. Cultural and Communication Studies. Sebuah Pengantar Paling Komprehensif. Yogyakarta : Jalasutra.

Hall, Stuart. 2011. Representation's Meaning. London : SAGE Publication.

Herdini, Heri. 2012. Estetika Karawitan Sunda. Panggung, 22 (3), 256-266.

Kusmayadi, Suyitno, dan Maryaeni. 2017. Jurnal Pendidikan: Teori, Penelitian, dan Pengembangan, 2 (7). 902-907.

Munir. 2013. Multimedia Konsep \& Aplikasi dalam Pendidikan. Bandung : Alfabeta.

Noviani, Ratna. 2005. Jalan Tengah Memahami Iklan, Antara Realitas, Representasi, dan Simulasi. Yogyakarta : Pustaka Pelajar.

Piliang, Yasraf Amir. 2004. Semiotika Teks: Sebuah Pendekatan Analisis Teks. Jurnal Mediator, 5 (2). 189-198.

Rosidi, Ajip. 2010. Mencari Sosok Manusia Sunda. Jakarta : PT Dunia Pustaka Jaya. 
Siswanto, Dwi. 2010. Pengaruh Pandangan Hidup Masyarakat Jawa terhadap Model Kepemimpinan. Jurnal Filsafat, 20 (3). 197-216.

Soewardikoen, Didit W. 2013. Metodologi penelitian Visual Dari Seminar ke Tugas Akhir. Bandung : Dinamika Komunika. 